\title{
THE RULE OF LAW AND LEGAL PLURALISM IN MALAYSIA
}

\author{
Constance Chevallier-Govers*
}

\begin{abstract}
In Malaysia, Islam is the religion of the state, although other religions may be practised in peace and harmony. Having inherited the English common law tradition at its independence in 1957, Malaysia is neither a secular state nor an Islamic theocracy. As a matter of fact, the Malaysian Constitution has brought Islamic law under the legislative powers of the federal States. Historical developments have thus led to the existence of two sets of law: common law and sharī ah law. Legal pluralism in Malaysia applies foremost to personal status, but also to some aspects of criminal law. The sharī ah as well as legal pluralism seem to question the rule of law in Malaysia. This two-fold aspect of the rule of law will be analysed in this article. The formal definition of the 'rule of law' implies the respect for the hierarchical principle and the Constitution's supremacy. It will be explained to what extent legal pluralism in Malaysia is challenging the supremacy of the Constitution. Nevertheless, the hierarchical principle is not a goal in itself, and the material definition of the 'rule of law' will also be discussed. The second part of this article will focus on potential human rights issues that are implied by the notion of legal pluralism and by sharī ah law in Malaysia.
\end{abstract}

\section{Introduction}

In Malaysia, two sets of law coexist: common law and sharī 'ah law. The Malaysian legal pluralism is rooted in colonial legacies: the coexistence of different normative or legal orders and a dual system of courts are the result of the country's colonial experience. ${ }^{1}$ Prior to British rule, Islamic law was of great importance. ${ }^{2}$ The earliest record of Islamic law in what is now Malaysia is to be found on the Terengganu stone inscription, which dates back to $1303 \mathrm{CE}$. It mentions the punishments for certain offences, following the various provisions given in the Qur'ān and the Sunnah. ${ }^{3}$ In pre-colonial Malaysia, the Sultans in each of their respective States were not only the heads of the religion of Islam but also the political leaders in their respective realms. In this sense they were 'Islamic states' with courts staffed with $q \bar{a} d \bar{l} \mathrm{~s}$ (Islamic judges) and enforcing the sharī $a h$. Under the treaties made by the

* Constance Chevallier-Govers is Associate Professor of Public Law at the University of Grenoble. 
Malay Sultans with the British, the Sultans agreed to receive British Residents or Advisers and to follow their 'advice' in all matters of administration - except in matters pertaining to Islamic religion and Malay custom (adat). Also upon British 'advice', the Malay Sultans set up civil courts, which were chaired by British judges. In the absence of legislation applicable to the matter, those judges tended to refer to the law prevalent in England. In this way, the English law of torts and the English rules of equity were introduced into the Malay states.

As a constitutional state, the contemporary Federation of Malaysia-comprising 13 states and three federal territories - is formally endorsing the principles of a democratic constitutional state - namely democracy, checks and balances, rights and liberties and the rule of law. ${ }^{4}$ The Constitution adopted in 1957 used the Western liberal constitutional model - especially the British Westminster model of parliamentary democracy - but it took into account the existence of collective identities within Malaysian society. Besides a bill of rights, containing an enumeration of the classical individual rights and liberties (Articles 5 to 13), the Malaysian Constitution also accepts group-specific rights and foresees the possibility for positive action policies for Malays.

According to Article 3 of the Constitution, Islam is the official religion of the Federation, although other religions may be practised in peace and harmony anywhere in the country. In this way, Malaysia is neither a secular nor an Islamic state. ${ }^{5}$ In the Che Omar ruling of 1988, the Federal Court has asserted that the shari ${ }^{-} a h$ was not the supreme law of the land. ${ }^{6}$ Furthermore, the Constitution accommodates legal pluralism regarding family and personal matters and, to a certain extent, regarding criminal law. Malaysia inherited the English common law tradition at its independence. However, the Constitution has brought Islamic law under the legislative powers of the States. As a matter of fact, the historical developments in Malaysia have led to the existence of two sets of law, which are recognised by the Constitution: one for non-Muslims and one for Muslims. Non-Muslims (Malaysian and foreign) are subject only to secular law and secular courts. Muslims (both Malaysian and foreign), on the other hand, are subject to both secular law and sharī'ah law. In this manner, Muslim Malaysians are thus subject to two sets of laws. Sharī 'ah law in Malaysia is under the jurisdiction of 13 separate states with their own interpretations. The organisation and procedure of the Islamic courts are a power attributed to the 13 State legislators. ${ }^{7}$ Legal pluralism in Malaysia will be apprehended only through the prism of sharī'ah law. Indigenous customary law (adat) will not be mentioned, even if it constitutes one aspect of legal pluralism in Malaysia.

The sharī 'ah as well as legal pluralism question the rule of law in Malaysia. ${ }^{8}$ In the following study, two definitions of the rule of law will be discussed. ${ }^{9}$ Forged in the late nineteenth century within German legal doctrine, the rule of law in the 
twentieth century has seen appreciable inflections. The totalitarian challenge led beyond the purely formal definition, based on the idea of hierarchy, in favour of a substantial emphasis in order to guarantee legal certainty and fundamental rights. The formal definition refers to the hierarchical principle, according to which all inferior law should conform to the superior law. The material definition takes into account the content of the law and implies that the law should not only conform to the superior law but it should also conform to human rights.

\section{The Formal Definition of the Rule of Law}

In Malaysia, Islamic law is subject to the supremacy of the Constitution and the federal law. Article 4 of the Constitution declares that the Constitution is the supreme law of the land, such that incompatible legislation is void. ${ }^{10}$ Article 75 of the Constitution stipulates that in case of conflict between the federal law and state law, federal law shall be applicable. The supremacy of the Constitution means that native law, received law and religious legal practice are subject to the constitutionality test. Two issues are related to the hierarchical principle, namely the distribution of legislative power between States and Federal legislatures and the distribution of jurisdiction between sharī $a h$ and civil courts.

\section{Distribution of legislative power between state and federal legislatures}

The constitutional framework of distribution of power between State and Federal legislatures seems to be quite clear: sharī $a h$ law is under the responsibility of the States (1). There are nevertheless some discrepancies between the Federal Constitution and States sharī ah Laws (2). Judicial review should be a remedy but it is more notional than real (3).

(1) Constitutional framework: Article 74 of the Constitution regulates the distribution of legislative powers between the Federation and the States and refers to the lists of the Ninth Schedule. ${ }^{11}$ This Ninth Schedule of the Federal Constitution sets out the Federal and States lists containing subjects on which the Federal (List I) and States (List II) government can legislate. In addition, there is a concurrent list of subjects (List II) on which both the Federation and the States can legislate.

The State List (List II) enumerates 13 areas for which State Assemblies have exclusive power. ${ }^{12}$ The first paragraph foresees that except with respect to the Federal Territories of Kuala Lumpur and Labuan, this is the jurisdiction of the States:

- Islamic Law and personal and family law of persons professing the religion of Islam come under State competences including Islamic law relating to succession, marriage, adoption, divorce; 
- creation and punishment of offences by persons professing the religion of Islam against the precepts of that religion, except in regards to matters included in the Federal list;

- organisation and procedure of shari 'ah courts, which shall have jurisdiction only over a person professing the religion of Islam and in respect only of any of the matters included in this paragraph, but shall not have jurisdiction in respect to offences except in so far as conferred by federal law; control of propagating doctrines and beliefs among Muslims.

The term 'Islamic law' in Schedule 9 List II, Paragraph 1 does not refer to Islamic law in its entirety but only to such areas of Islamic law as are explicitly enumerated in that paragraph. ${ }^{13}$ As Islamic law is administered by the respective States, there is thus a lack of uniformity in the administration of Islamic law in Malaysia. ${ }^{14}$

(2) Discrepancies between the Federal Constitution and criminal sharì ah laws of the States: Individual States can create sharī'ah criminal offences, provided four conditions are met: it is an act against the precepts of Islam and it is not already a criminal offence according to federal law. It can only apply to a person professing the religion of Islam, and the punishment is limited according to the 1965 Act, often referred to as the '3/5/6 formula' ( 3 years jail, a fine of 5,000 Malaysian Ringgit (RM), 6 strikes with the rotan stick).

The Malaysian States have, nevertheless, adopted criminal offences enactments which are to some extent unconstitutional because of overlapping federal powers. ${ }^{15}$ Some of the offences appear to overlap with offences already existing in the Penal Code and other federal laws. Liwāt (the homosexual version of sodomy), for example, overlaps with "sexual intercourse against the order of nature" and "outrages on decency" (sections 377A and 377D of the Penal Code, respectively). Muncikari (procuring) and "indecent acts in a public place" overlaps with "outrages on decency" (section 377D of the Penal Code which includes "procures or attempts to procure") and "gambling" with "gaming in a common gaming house" and "gaming in public" (sections 6 and 7, respectively, of the Common Gaming Houses Act 1953 (Act 289)).

Sharī $a h$ law differentiates two kinds of offences: $h u d \bar{u} d$ and $t a{ }^{\prime} z \bar{\imath} r .{ }^{16} H u d \bar{u} d$ crimes, which are considered the most serious ones, are those which are punishable by a pre-established punishment found in the Qur'ān. These crimes are found by an exact reference in the Qur'ān to a specific act and a specific punishment for that act. $T a ' z \bar{\imath} r$ crimes are less serious than the $h u d \bar{u} d$ and are not found in the Qur'ān so the Islamic judges are free to determine an appropriate punishment. In Kelantan and Terengganu, on top of these Criminal Offences Enactments they have adopted hudūd laws: the Kelantan Shariah Criminal Code Enactment of 1993 and the Terengganu 
Sharī'ah Criminal Offence Enactment (hudūd and qișașs of 2002. These strict hudūd laws adopted by Kelantan and Terengganu States are not implemented. But if they were, they would be in breach with federal law in so far as the punishments foreseen in these laws are more than the ' $3 / 5 / 6$ formula' imposed by the Shari 'ah Courts Act of 1965. For example, the punishment for sodomy, illicit sex between unmarried persons $(z i n \bar{a})$ or apostasy is death.

Article 75 of the Federal Constitution clearly provides that "If any State law is inconsistent with a federal law, the federal law shall prevail and the State law shall, to the extent of the inconsistency, be void." It should be the responsibility of the courts to declare some provisions of these laws void.

(3) Lack of judicial review: The Federal Court has the power to review federal and state legislation on the ground of unconstitutionality. In Article 4(1), the Federal Constitution declares itself to be the supreme law of the federation. According to Article 128(1), ${ }^{17}$ the Federal Court is conferred the exclusive jurisdiction to settle disputes "on any question" between the States or between the Federation and any States, and also, more specifically, on the question as to whether a law passed by parliament or the legislature of a State is invalid on the ground that it makes provisions with respect to a matter regarding which parliament or the legislature of a State has not power to make laws.

Article 128(2) also gives the Federal Court a referral jurisdiction. In any proceedings before another court, if a question arises as to the effect of any provisions of the Constitution, the Federal Court shall determine that question and remit the case back to the Court to be disposed of in accordance with such determination. The Yang di-Pertuan Agong, Malaysia's paramount ruler and Head of State, ${ }^{18}$ may also refer to the Federal Court for its position on any question as to the effect of any provision of this Constitution which has arisen or appears to him likely to arise. ${ }^{19}$ The courts have the constitutional duty to enforce compliance and observance by the State and the Federal Governments of all the supremacy of the Constitution by virtue of the power conferred by Articles 4(3) and 4(4). But as they renounce this power, judicial review seems to be "more notional than real". ${ }^{20}$

One can identify two causes for the judges' reluctance to exercise judicial review. The first explanation can be found in the British tradition of parliamentary supremacy. Judges seem to be steeped in the British tradition of parliamentary supremacy which has no legal basis in so far as Malaysia has a written constitution unlike in the United Kingdom. ${ }^{21}$ For example, in the case of Loh Kooi Choon v. Government of Malaysia [1977] 2 MLJ 187, it was stated by the court that "the question of whether the impugned Act is harsh and unjust is a question of policy to be debated and decided by Parliament and therefore not fit for judicial determination". In a way, the rule by law has ruined the rule of law. 
The second explanation to the judges' reluctance is the lack of independence of the judiciary resulting from the 1988 crisis. Before 1988, there had been a growing freedom of the judiciary, and a short period of judicial renaissance. Following a string of judicial rulings against the Government in the 1987-88 period, the Government moved to strip the judiciary of its power of judicial review. Former Prime Minister Tun Dr Mahathir Mohamad, during his term in office, eventually sacked Chief Justice Salleh Abas and two other Supreme Court judges. Ever since the attack on the judiciary in 1988, the judiciary has repeatedly failed to uphold the rule of law and to rule with the independence of all powers, notably the executive.

\section{Distribution of jurisdiction between sharīa ah and civil courts}

The shari 'ah court system pre-dates the civil court system. Indeed, there was a court system prior to the British intervention, which was a system of one set of courts, the $q \bar{a} d \bar{l}$ courts. Today, Malaysia has a dual court system comprising the civil courts and the shari 'ah courts. ${ }^{22}$ The latter have jurisdiction to apply shari' $a h$ law to Muslims and civil courts have jurisdiction to apply civil law to Muslims and non-Muslims (1). The Constitution was amended in 1988 to clarify the distribution of jurisdiction (2) but it has not solved all the problems raised by the existence of a dual court system (3). Some ways ahead are suggested to avoid tussle situations (4).

(1) Constitutional framework: Originally the Constitution referred only to the composition of civil courts in Article 121. Though sharī ah courts were mentioned in Schedule 9 of article 74 which prescribes that the States are responsible for the "organisation and procedure of shari ${ }^{-} a h$ courts, which shall have jurisdiction only over persons professing the religion of Islam and in respect only of any of the matters included in this paragraph, but shall not have jurisdiction in respect of offences except in so far as conferred by federal law".

Secular courts used to be in a position of more authority until the 1988 amendment to the Constitution which redefined the relationship between secular courts and shari 'ah courts. The amendment 121(1A) provided that the High Courts were to "have no jurisdiction in respect of any matter within the jurisdiction of the shari 'ah courts". ${ }^{23}$ It was a very simple amendment. It merely says that where the shari 'ah courts have jurisdiction over a matter, the common law courts do not have jurisdiction over it. The aim of this change was to prevent litigants from appealing sharì ah court decisions to the High Court. ${ }^{24}$ However, different interpretations of this amendment emerged. ${ }^{25}$

(2) Different interpretations of the 1988 Amendment: Two different interpretations of Article 121(1A) resulting from the 1988 amendment can be identified: the parallel 
and the hierarchical interpretations. According to the parallel interpretation, sharī $a h$ courts and civil courts form two separate courts systems. Salbiah Ahmad asserts that

State Shariah courts are not courts inferior to the federal courts as the term 'inferior court' is understood in terms of appeal and judicial review by superior courts over inferior courts. The State Shariah courts are in a separate hierarchy to that of the federal civil courts. There is no right of appeal from the State Shariah courts to the federal civil courts. There is no power of judicial review by the federal high court over the State Shariah court. ${ }^{26}$

This interpretation is commonly adopted and reflects the state of the case law today. On any issue that is connected to Islamic law whether it is within or outside the jurisdiction of the shari 'ah courts, the civil courts are extremely reluctant to pronounce a judgment even if issues of jurisdiction, constitutionality and human rights are involved. In doing so they are subordinating human rights in Article 5 to 13 to the power of the States to legislate on Islam under 9th Schedule. The implication of such an interpretation is that Schedule 9 to Article 74 and Article 121(1A) are given priority over Article 4 asserting the supremacy of the Constitution and over Articles 5 to 13 on fundamental rights.

According to the hierarchical interpretation, shari ' $a h$ courts, as State courts, are submitted to civil courts, as federal courts. Some authors, like Rasamani Kandiah, consider that

the amendment does not purport to oust the jurisdiction of the High Court to review decisions of the Shariah Courts. It merely says, in effect, that the ordinary courts cannot exercise the Shariah court's jurisdiction a position which, it should be noted, applies to any inferior jurisdiction: it is indeed a cardinal principle of judicial review that the court cannot substitute its decision for that of the inferior jurisdiction whose decision is reviewed. It does not therefore seem possible that the Shariah courts, by this small amendment, have been converted into a totally separate legal system [...]. As things stand the civil courts exercise the power of judicial review and this is of course part of the judicial power. Nothing in clause $1 \mathrm{~A}$ attempts to interfere with this proposition. ${ }^{27}$

This is also the opinion of Mohammad Hashim Kamali, according to whom

Article 121 was to address problems arising out of conflicting jurisdiction and not to create a new jurisdiction or introduce any basic changes in the status of the civil courts as of general jurisdiction in the country. Sharī ah courts are not integrated into federal legal system but belong to State jurisdiction. ${ }^{28}$

The implication of this interpretation is that Article 4, asserting the supremacy of the Constitution, and Articles 5 to 13 on fundamental rights are given priority over Schedule 9 to Article 74 and over Article 121(1A). 
In the Malaysian Constitution, there is no provision on the basic structure of provisions which cannot be modified because they are more important than the other ones. For example, in France the provision which prescribes that France is a republic is part of the basic structure, as in Germany, and the provisions on federalism and human rights cannot be amended. Such provisions on basic structure are lacking and all the provisions of the Malaysia Constitution are considered to be of the same importance.

(3) Remaining issues regarding the distribution of jurisdiction between sharī'ah and civil courts: When the subject matter falls within the jurisdiction of the $\operatorname{sharl}^{-} a h$ court but one of the parties is a non-Muslim, which court is to hear the case? Civil courts have no jurisdiction over sharì 'ah law, but sharī'ah courts, in turn, have no jurisdiction over non-Muslims. Indeed according to Schedule 9 list 2, "Shariah courts shall have jurisdiction only over persons professing the religion of Islam".

Many cases raise the question of the effects of conversion to Islam on civil marriages. According to sharī ah law, a Muslim cannot marry a non-Muslim. ${ }^{29}$ Marriages between non-Muslims in Malaysia are registered under the civil law known as the Law Reform (Marriage and Divorce) Act 1976 (Act 164) (known as 'LRA'). Section 3 of the LRA provides that the Act shall not apply to "a Muslim" or to "any person who is married under Islamic law". The exception to this rule lies in section 3(3) which provides that the court may still grant a decree of divorce under section 51 "where one party to the marriage has subsequently converted to Islam and such decree shall be valid and binding against the party to the marriage of who has converted to Islam". Nevertheless, section 51 does not allow the converted spouse to file for a divorce in front of the civil court. According to Islamic law, the marriage is terminated three months after the conversion if the other spouse does not also convert to Islam. The converted spouse is thus free to marry according to Islamic law. Most often it is the man who converts to Islam leaving his wife without any ancillary relief or maintenance. Sometimes the converted spouse even files for a divorce in the shari ' $a h$ court resulting in two divorce settlements, one from the shari ${ }^{-} a h$ court and one from the civil court. ${ }^{30}$ The Federal Court has recently asserted that the converted husband could still seek divorce in the shari' $a h$ court albeit the rulings made by the shari 'ah court would not bind the civil court. ${ }^{31} \mathrm{~A}$ draft amendment of section 51 of the LRA is being discussed in the federal parliament to make sure that the converting spouse has fulfilled all his obligations under the civil law before converting to Islam (ancillary relief, maintenance of the spouse and children, custody of the children). ${ }^{32}$

When one of the spouses converts to Islam, it happens that he or she tries to unilaterally convert his children. A few cases have raised the question whether only one of the parents could convert children under the age of 18. The Administration 
of Islamic Law (Federal Territories) Act 1993 gives the right to a converted parent to convert his or her children from a civil marriage without the knowledge and consent of the other parent. The Federal Court was recently seized and ruled that any parent has a right to convert the child of marriage to Islam. It held that the word "parent" in Article 12(4) of the Federal Constitution which states that the religion of a person under the age of 18 shall be decided by his parent or guardian, means a single parent. ${ }^{33}$

Concerning apostasy, an issue has emerged as to determining which court should have jurisdiction to authorise a Muslim to conversion away from Islam. ${ }^{34}$ Every Malaysian has an identity card which contains his personal information and for Muslims their religion is also mentioned. The National Registration Administration (NRD) is responsible for issuing these cards. In 2007, the Supreme Court held - in the Lina Joy case ${ }^{35}$ - that the NRD policy of requiring a certificate of apostasy from the shari ${ }^{\prime} a h$ court was lawful. The question whether Lina Joy was a Muslim or not was a decision exclusively for the Islamic courts. Thus a Muslim who wishes to declare apostasy must first get the shari 'ah court to confirm that he or she has left the religion of Islam. Until the act of renunciation is validated by the shari 'ah court, a Muslim is deemed to be a person of the Muslim faith. The problem is that shari' $a h$ courts do not easily hand out these certificates because in some States apostasy is a criminal offence and where it is not a criminal offence there is no provision giving them this power. Apostasy is therefore practically impossible. This ruling raises also two other questions. Why should the sharī ah court be competent concerning the faith of a non-Muslim? Finally, professing is a matter of inner feeling. It is not something that can be decided by a court either sharì $a h$ or civil. This goes far beyond the problem of distribution of jurisdiction.

(4) Possible remedies to solve conflict of jurisdiction: Without any constitutional amendment it should be possible to invoke the advisory jurisdiction of the Federal Court under Articles 128 and 130 of the Constitution to address conflicts of jurisdiction. ${ }^{36}$ However, these provisions are very seldom used. Some academics have therefore suggested introducing more important changes in the constitutional framework in order to solve these problems of distribution of jurisdiction between sharī'ah and civil courts.

The first solution would be to unify the civil and the shari 'a $a$ courts at all levels which also would mean federalising the sharī ah courts. Persons qualified in civil law as well as persons qualified in Islamic law would be appointed judges of the same court at all levels. Islamic law cases, civil or criminal, would be heard by judges qualified in Islamic law. Non-Islamic law cases would be heard by judges qualified in civil law. If, in a case there would be issues involving both laws, two judges would sit, one from each discipline. The judge with Islamic law qualification 
would decide issues of Islamic law. The judge with civil law qualification would decide the other issues. The final judgment of the court would be given by both of them, jointly ${ }^{37}$ This would require a constitutional amendment and it would be a very sensitive issue. Even if the question of jurisdiction would be thus settled, it would not address the question of conflicting laws.

Another proposition is to create a body responsible in cases of conflict of jurisdiction. There should be a mechanism put in place where a distribution body manned by judges familiar with both civil and shari 'ah laws adjudicate on this matter. ${ }^{38}$ This distribution body would have as its only power the allocation of difficult cases.

The $\operatorname{shar}^{-}{ }^{\dagger} a h$ as well as legal pluralism question the formal definition of the rule of law by challenging the Constitution's supremacy. In a democracy it is important that this hierarchical principle be respected but it is not a goal in itself. Another major aspect is that the law respects some fundamental values, called human rights.

\section{Material Definition of the Rule of Law}

The material definition of the rule of law is a definition according to the content of the law which has to conform to human rights. Some human rights are protected by the Malaysian Constitution (Articles 5 to 13$)^{39}$ and in this way the material and formal definitions of rule of law converge. Nevertheless one also has to confront Malaysia's legal pluralism to international standards of human rights and to analyse potential collisions between sharì ah law in Malaysia and human rights.

Malaysia is not party to the main United Nations Conventions on human rights such as the International Covenant on Civil and Political Rights (ICCPR). The only binding obligations of Malaysia are regarding two international treaties: the Convention on Elimination of Discrimination against Women (CEDAW) of 1979 ratified with reservations in $1995^{40}$ and Convention on the Rights of the Child (CRC) of 1989 ratified with reservations by Malaysia in $1995 .{ }^{41}$ In order to promote and protect human rights in Malaysia, the Government has established an independent Commission on Human Rights under the Human Rights Commission of Malaysia Act 1999. ${ }^{42}$ Section 2 of this Act defines 'human rights' as referring to the "fundamental liberties as enshrined in Part II of the Federal Constitution". Furthermore, section 4(4) of the Act provides that regard shall be had to the Universal Declaration of Human Rights 1948 (UDHR) to the extent that is not inconsistent with the Federal Constitution. ${ }^{43}$ This means that whatever rights and liberties not mentioned in Part II but referred to in the UDHR must be considered provided that there is no conflict with the Constitution.

Legal pluralism and sharì 'ah in Malaysia raise many issues concerning human rights. Actually it is not itself legal pluralism which is concerned but more specifically 
sharī $a h$ law applied in Malaysia. This study will focus on potential breaches to freedom of religion and to women's rights resulting from the implementation of sharīà law.

\section{Freedom of religion}

Article 11 of the Constitution provides for freedom of religion: "Every person has the right to profess and practice his religion and, subject to Clause (4), to propagate it" $^{\prime 44}$. Clause 4 empowers the State legislatures to enact anti-propagation laws to regulate the propagation of other religions amongst the Muslims. Hence there is a constitutionally backed prohibition to proselytise among the Muslims.

Three threats to freedom of religion can be identified: apostasy (1), interreligious marriages (2) and special status of Malays (3).

(1) Apostasy: Some States have created penal offences to punish apostasy. Kelantan and Terengganu have adopted $h u d \bar{u} d$ laws punishing by death apostates. These laws are not yet implemented. Some other States like Malacca, Perak and Sabah have also criminalised apostasy by imposing fines not exceeding RM 3,000 and/ or imprisonment of not more than two years. The penal punishment of apostasy raises difficult constitutional issues. It is a breach to Article 11 of the Constitution on freedom of religion, which should be interpreted as broad enough to permit change of faith. Article 11 does not explicitly forbid apostasy. ${ }^{45}$

The right to convert away from one's religion is alluded to in Article 18 of the Universal Declaration of Human Rights (UDHR) 1948. It declares that "Everyone has the right to freedom of thought, conscience and religion; this right includes freedom to change his religion or belief, and freedom [...]." The UDHR has been given partial recognition by section 4(4) of Malaysia's Human Rights Commission Act 1999 but only to the extent that is not inconsistent with the Federal Constitution. The UDHR is a declaration adopted by the General Assembly of the United Nations without binding effect but most of its content has been integrated within the two International Covenants of 1966. Article 18 of the International Covenant on Civil and Political Rights 1966 (ICCPR) does not mention explicitly the right to change religion; it only mentions the right to adopt one's religion. ${ }^{46}$ Nevertheless according to United Nations Human Rights Committee, this should be interpreted as including the right to change religion. ${ }^{47}$ Malaysia is not party to the ICCPR. So except by admitting that the UDHR is binding as an international customary law, no provision of international human right law is applicable to Malaysia and the only reference is therefore the Malaysian Constitution.

Some States do not criminalise apostasy but impose a forced rehabilitation to the apostate. This is an interference with personal liberty guaranteed by Article 5(1) of the Constitution. A murtad (apostate) may also claim that the rehabilitation 
law violates his or her right of freedom of speech provided for by Article 10 of the Constitution but also Article 12(3) which says that no person shall be forced to receive instruction or take part in any ceremony or act of worship of a religion other than his own.

(2) Interreligious marriage: The fact that, according to sharī 'ah law implemented in Malaysia, Muslims cannot marry non-Muslims results in a ban of interreligious marriage for Muslims. This can be analysed as a violation of freedom of religion as guaranteed by Article 11 of the Constitution. It is also a breach to Article 10 of the Constitution on freedom of speech and association. Finally, it encroaches an internationally recognised right to marry and to found a family cited in Article 23 of the ICCPR. This specific right is not mentioned in the Malaysian Constitution and Malaysia is not party to the ICCPR. This right to marry is also guaranteed by Article 16 of the UDHR.

(3) Constitutional status of the Malays: The status of Malays is determined by the Constitution. ${ }^{48}$ Article 160 defines a 'Malay' as a person who is a Malaysian citizen, born to a Malaysian citizen, who professes to be a Muslim, habitually speaks the Malay language, adheres to Malay customs, and is domiciled in Malaysia or Singapore. ${ }^{49}$ Malays can theoretically convert out of Islam, but in practice this is very difficult, as shown above. ${ }^{50}$ The question remains whether a Malay apostate would lose his or her identity or lose the 'status' of being a 'Malay'. It seems, until now this issue has never been taken to the court. ${ }^{51}$ Here we have two conflicting constitutional provisions: Article 11 on freedom of religion and Article 160 on Malay identity. It is in these kinds of cases that a provision on the basic structure would be of great help.

\section{Women's rights according to sharī $a h$ law as implemented in Malaysia}

Article 8 of the Constitution states that, "all persons are equal before the law and entitled to the equal protection of the law". It did not first identify gender as a ground for discrimination. On 1 August 2001, Article 8(2) was amended to include the word 'gender'. Clause 5 of Article 8 provides that constitutional provisions concerning equality before the law and non-discrimination on grounds of religion, gender, race, etc. explicitly exclude their application to the legislation concerning personal laws. This is an important limit to the non-discrimination principle. Malaysia has ratified the CEDAW in 1995 but with reservations. ${ }^{52}$ Malaysia's accession to CEDAW is ultimately subject to the understanding that its provisions do not conflict with the provisions of the sharī ah law and the Constitution. Concerning discrimination towards women, Malaysia is therefore submitted to the review by the Committee created by the CEDAW. It is mainly regarding marriage that Muslim women suffer 
injustices under sharī 'ah law implemented in Malaysia (1) but there are also some other issues to be mentioned concerning States' criminal enactments (2).

(1) Status of Muslim women regarding marriage: Muslim family law falls under the legislative power of the Malaysian States. This construction entails that there are many different versions of Islamic law enactments in the different member States. The Islamic Family Law Act (IFLA) of 1984 adopted by the Federal Parliament for the Federal Territories was designed to serve as a model for the other Malaysian States. ${ }^{53}$ However, family law in some States deviates from the federal model in several important respects. Here we shall not put the emphasis on the discrepancies between the IFLA and States' sharī 'ah laws in family matters but only take the IFLA as reference illustrating the trends of Islamic family law in Malaysia.

According to the IFLA and all the Family States laws, Muslim women do not benefit from equal rights to enter into marriage as the approval of the wāli (the woman's guardian for marriage) is needed, even if the consent of the wife is now required. Section 13 of IFLA states that a marriage shall not be recognised or registered under this Act unless both parties freely consent to the marriage and either the $w \bar{a} l \bar{l}$ or in the absence of wāli the shari 'ah judge has also consented. ${ }^{54}$ Furthermore women do not have equal right to dissolve marriage. Talāq, which is the unilateral repudiation of women, is still implemented in Malaysia. ${ }^{55}$ The IFLA seeks to limit arbitrary unilateral repudiation (talāq) by requiring the husband to apply to the court for permission to pronounce the talāq in court. Extra-judicial talāq is subject to punishment by fine and/or imprisonment. So by paying a fine a man can unilaterally repudiate his wife. But even a judicial tala $q$ is discriminatory towards Muslim women as they cannot unilaterally end marriage and can obtain a divorce only on limited grounds (not receiving maintenance, being abused, and cruelty). Muslim women do not have equal rights regarding guardianship: the father is the only legal guardian but the mother can have custody. A woman (but not a man) can lose custody on several grounds, including 'immorality'. Finally, polygamy is only permitted for Muslim men. According to Section 23 of IFLA, the right to practise polygamy may only be exercised with the court's permission and if four conditions are met: such marriage is just and necessary, the husband has financial means to support more than one wife, he is to treat the co-wives equally and not to cause harm to the existing wife, and finally the consent of the existing wife is needed. This practice is still discriminatory towards women as such right is not recognised for them.

All these issues concerning the status of Muslim women regarding marriage have been pointed out by the CEDAW Committee in its 2006 Report. ${ }^{56} \mathrm{~A}$ new bill amending the IFLA has been finalised and awaits submission to Parliament. 
(2) Issues concerning women in the States'shari' ah criminal offences enactments: In the sharī'ah criminal offences enactments of the States there is no distinction between zinā (illicit sex between unmarried persons) and rape. For example, while the Criminal Offences Enactment of Kelantan ${ }^{57}$ addresses the subject of zinā it does not mention rape at all. Zinā has been given a broad definition consisting of sexual intercourse between a man and a woman who are not married. In case of zina $\bar{a}$, pregnancy or delivery of a baby by an unmarried woman shall constitute evidence on which to find her guilty of zinā. This constitutes discrimination towards women in so far as if a woman is raped and gets subsequently pregnant, she will be guilty of zinā.

Some offences are addressed only to women, which is discriminatory. For example, according to section 48 of Terengganu Criminal Offences Enactment, ${ }^{58}$ it is an offence for a virgin woman to abscond from the custody of her parents or legal guardian. Or according to section 35, "any woman who in any public place exposes any part of her body that arouses passion" is liable for a fine of RM 1,000 or a jail term of up to six months.

The non-governmental organisation Sisters in Islam has analysed Kartika's caning sentence $^{59}$ as a further discrimination towards Muslim women compared to other women who cannot be caned as civil law does not prescribe caning for women but only for men under 50 years old. ${ }^{60}$ Whipping of women under sharī $a h$ criminal offences legislation contradicts civil law where women are not punishable by caning under section 289 of the Criminal Procedure Code. Moreover caning could be considered as a form of cruel, inhuman and degrading punishment prohibited by ICCPR. Nevertheless Malaysia is not part either of this treaty or of the United Nations Convention against torture and other cruel, inhuman or degrading treatment or punishment of 1984 and there is no provision in the Constitution on the prohibition of torture or cruel, inhuman and degrading punishment.

The constitutional provisions on human rights are in some ways incomplete. Concerning the discrimination against women, clause 5 of Article 8 authorises discrimination regarding personal law, which means regarding all issues important to women. The Constitution lacks some fundamental rights, like the ban of torture or cruel, inhuman and degrading punishment. As Malaysia is not submitted to the major legally binding instruments on human rights, sharī'ah law is therefore not confronted by international human right standards.

\section{Conclusions and Recommendations}

The dual legal system in Malaysia is a very interesting way of enabling a multicultural society to peacefully coexist. However there are some faults in the system such as a lack of effective means to guarantee the Constitution's supremacy. If such 
mechanisms were installed, the Malaysian legal system could be seen to some extent as a model of pluralism. Malaysia is an original example of hybridising and syncretism. The issues on the compliance to human rights are more intrinsically related to sharì ah law than to legal pluralism in itself. Some Muslim countries such as Morocco have managed to reform their Islamic family law to make it compliant to international human right standards, which should also be possible in Malaysia.

Some suggestions on the functioning of legal pluralism and the shari 'ah are proposed as tracks of reflection:

- The creation of a distribution body to allocate sensitive cases either to sharī ah or to civil courts. There should be a mechanism put in place with a distribution body manned by judges familiar with both civil and shari ${ }^{-} a h$ laws. ${ }^{61}$ This distribution body would have as its only power the allocation of difficult cases. In the case of a tie, the chief Justice would allocate the case either to civil or to sharī'ah courts.

- The insertion of a basic structure provision in the Constitution. Articles 5 to 13 of the Constitution protecting human rights should be declared as being part of the basic structure of the Constitution. Thereby other articles of the Constitution would have to be interpreted in accordance with the latter.

- Joining the ICCPR. Malaysia should join the International Covenant on Civil and Political Rights (ICCPR), most probably with reservations concerning sharī'ah law. But at least a dialogue would emerge between Malaysia and the United Nations Human Rights Committee at the occasion of the periodical review.

- The adoption of a federal law on apostasy, taking as model Negeri Sembilan's enactment. On the basis of Article 76 of the Constitution, allowing the Federal Parliament to make laws with respect to any matter enumerated in the State List for the purpose of promoting uniformity of the States' laws, the Federal Parliament should pass a law on apostasy. It would take as example the Administration of Islamic Law Enactment of 2003 in Negeri Sembilan.

\section{Notes}

1. J. Vanderlinden, "Le pluralisme juridique", in: J. Gilissen (ed.), Le pluralisme juridique: Etudes (Etudes d'histoire et d'ethnologie juridiques 11) (Brussels: Centre d'histoire et d'ethnologie juridiques, Institut de sociologie, Université Libre de Bruxelles, 1972), 19.

2. Virginia Matheson Hooker, A Short History of Malaysia: Linking East and West (Crows Nest NSW [Australia]: Allen and Unwin, 2003), 345; Cheah Boon Kheng, Malaysia: The Making of a Nation (Singapore: Institute of Southeast Asian Studies, 2002), 263.

3. This is the law relating to the punishment for zinā.

4. Shad Saleem Faruqi, Document of Destiny: The Constitution of the Federation of Malaysia (Petaling Jaya, Selangor [Malaysia]: Star Publications Berhad, 2008), 125; J.C. Fong, Constitutional Federalism in Malaysia (Petaling Jaya, Selangor [Malaysia]: Sweet and Maxwell Asia, 2008), 7. 
5. Shamrahayau A. Aziz, "Some Thoughts on the Relationship Between Law and Religion in Malaysia", Current Law Journal 4 (2009), xxii.

6. Che Omar [1988] 2 Malayan Law Journal, 55.

7. Fong, Constitutional Federalism, 91.

8. Ahmad Masum, "The Rule of Law under the Malaysian Federal Constitution", Malayan Law Journal 6 (2009), cxii.

9. Jacques Chevallier, L'état de droit (Paris: Montchréstien, 2010, 5th ed.), 158.

10. Art. 4(1) of the Constitution says: "This Constitution is the supreme law of the Federation and any law passed after Merdeka Day which is inconsistent with the Constitution shall, to the extent of inconsistency, be void".

11. Article 74 Constitution:

(1) Without prejudice to any power to make laws conferred on it by any other Article, Parliament may make laws with respect to any of the matters enumerated in the Federal List of the Concurrent List (that is to say, the First or Third List set out in the Ninth Schedule).

(2) Without prejudice to any power to make laws conferred on it by any other Article, the Legislature of a State may make laws with respect to any of the matters enumerated in the State List (that is to say, the Second List set out in the Ninth Schedule) or the Concurrent List.

(3) The power to make laws conferred by this Article is exercisable subject to any conditions or restrictions imposed with respect to any particular matter by this Constitution.

(4) Where general as well as specific expressions are used in describing any of the matters enumerated in the Lists set out in the Ninth Schedule the generality of the former shall not be taken to be limited by the latter.

12. Ninth Schedule (List II) of Article 74 of the Constitution:

1. Except with respect to the Federal Territories of Kuala Lumpur and Labuan, Islamic law and personal and family law of persons professing the religion of Islam, including the Islamic law relating to succession, testate and intestate, betrothal, marriage, divorce, dower, maintenance, adoption, legitimacy guardianship, gifts, partitions and non-charitable trusts; Wakafs and the definition and regulation of charitable and religious endowments, institutions, trusts, charities and charitable institutions operating wholly within the State; Malay customs. Zakat, Fitrah and Baitulmal or similar Islamic religious revenue, mosques or any Islamic public places of worship, creation and punishment of offences by persons professing the religion of Islam against precepts of that religion, except in regard to matters included in the Federal List; the constitution, organization and procedure of Syariah courts, which shall have jurisdiction only over person professing the religion of Islam and in respect only of any of the matters included in this paragraph, but shall not have jurisdiction in respect of offences except in so far as conferred by federal law, the control of propagating doctrines and beliefs among persons professing the religion of Islam; the determination of matters of Islamic law and doctrine Malay custom.

13. Shad Saleem Faruqi, "Jurisdiction of State Authorities to Punish Offences Against the Precepts of Islam: A Constitutional Perspective", 28 September 2005, available online at http://www. malaysianbar.org.my/constitutional_law/jurisdiction_of_state_authorities_to_punish_offences against_the_precepts_of_islam_a_constitutional_perspective.html (accessed on 1 July 2010).

14. Hamid Jusoh, The Position of Islamic Law in the Malaysian Constitution with Special Reference to the Conversion Case in Family Law (Kuala Lumpur: Dewan Bahasa dan Pustaka, 1991), 4-5; see also http://www.docstoc.com/docs/3776377/The-posiiton-of-Islamic-law-in-Malaysia (accessed on 1 July 2010).

15. Shariah Criminal Offences Enactment of Perlis, No.4/1993; Shariah Criminal Offences Enactment of Pulau Pinang, No.3/1996; Shariah Criminal Offences Enactment of Perak, No.3/1992; Shariah Criminal Offences Enactment of Selangor, No.9/1995; Shariah Criminal Offences Act of Federal Territory 1997; Shariah Criminal Offences Enactment of Negeri Sembilan, No.4/1992; Shariah Criminal Offences Enactment of Johor, No.4/1997; Shariah Criminal Offences Enactment of Kelantan, No.2/1985; Shariah Criminal Offences Enactment of Sabah, No.3/1995; Shariah Criminal 
Offences Enactment of Terengganu 2001; Shariah Criminal Offences Ordinance of Sarawak, No.6/1991.

16. Ahmad Mohamed Ibrahim, The Administration of Islamic Law in Malaysia (Kuala Lumpur: Institute of Islamic Understanding Malaysia (IKIM), 2000), 583.

17. Article 128 of the Constitution:

(1) The Supreme Court shall, to the exclusion of any other court, have jurisdiction to determine in accordance with any rules of court regulating the exercise of such jurisdiction -

(a) any question whether a law made by Parliament or by the Legislature of a State is invalid on the ground that it makes provision with respect to a matter over which Parliament or, as the case may be, the Legislature of the State has no power to make laws; and

(b) disputes on any other question between States or between the Federation and any State.

(2) Without prejudice to any appellate jurisdiction of the Supreme Court, where in any proceedings before another court a question arises as to the effect of any provision of this Constitution, the Supreme Court shall have jurisdiction (subject to any rules of court regulating the exercise of that jurisdiction) to determine the question and remit the case to the other court to be disposed of in accordance with the determination.

(3) The jurisdiction of the Supreme Court to determine appeals from a High Court or a judge thereof shall be such as may be provided by federal law.

18. Malaysia is a constitutional monarchy with an elected monarch as head of state. The position of the Yang di-Pertuan Agong (Malaysia's paramount ruler, HM the King) de facto rotates every five years among the nine Rulers of the Malay states.

19. Article 130 of the Constitution: "The Yang di-Pertuan Agong may refer to the Supreme Court for its opinion on any question as to the effect of any provision of the Constitution which has arisen or appears to him likely to arise, and the Supreme Court shall pronounce in open court its opinion on any question so referred to it."

20. Masum, "The Rule of Law", cxii.

21. Ibid.

22. Farid Sufian Shuaib, "Powers and Jurisdiction of Shariah Courts in Malaysia", Malayan Law Journal (2003), 32.

23. Introduced by the Act No. A704 of 10/06/1988.

24. Ahmad Ibrahim, "The Amendment to Article 121 of the Federal Constitution: Its Effect on Administration of Islamic Law, Malayan Law Journal 2 (1989), xvii.

25. Shuaib, "Powers", 145.

26. Salbiah Ahmad, "Islam in Malaysia: Constitutional and Human Rights Perspectives", Muslim World Journal of Human Rights 2, no. 1 (2005), available online at http://www.bepress.com/mwjhr/vol2/ iss1/art7 (accessed on 1 July 2010).

27. Rasamani Kandiah, Marriage and Dissolution Handbook (Kelana Jaya, Selangor [Malaysia]: LexisNexis 2007, 2nd ed.), 156.

28. Ibrahim, Administration, 56.

29. Section 10 of the Islamic Family Law (Federal Territories) Act 1984.

30. A divorced Muslim woman is entitled to reasonable maintenance from her husband. She is entitled to be maintained by her husband during the iddah period, during which husband and wife are considered $r u j \bar{u}$ ' i.e. resuming the conjugal relationship, which is approximately a period of three months. Three months is a very short period compared with the maintenance given by civil courts. The wife loses the right to maintenance if she is deemed to have denied the 'lawful wishes' of her husband.

31. Subashini Rajasingam v Saravanan Thangathoray, 27 December 2007, Federal Court [2008] Malayan Law Journal, 1.

32. Zaleha Kamaruddin, "Divorce Laws in Malaysia (Civil and Shariah)", Malayan Law Journal (2005), 227.

33. Subashini Rajasingam v Saravanan Thangathoray. 
34. Thio Li-ann, "Apostasy and Religious Freedom: Constitutional Issues Arising from the Lina Joy Litigation", Malayan Law Journal (2006).

35. Lina Joy, Federal Court [case report] Malayan Law Journal (2007), 620.

36. Ahmad Masum, "Freedom of Religion Under the Malaysian Federal Constitution", Current Law Journal 2 (2009), xiii.

37. Dato' Abdul Hamid bin Haji Mohamad, "Civil and Syariah Courts in Malaysia: Conflict of Jurisdictions", paper presented at the International Seminar on Islamic Law in the Contemporary World, organised by the Institute of Islamic Understanding Malaysia (IKIM), Kuala Lumpur, 24-25 October 2000.

38. Masum, "Freedom", xiii.

39. - Liberty of the person (Article 5);

- Prohibition of slavery and forced labour (Article 6);

- Protection against retrospective criminal laws and repeated trials (Article 7);

- Equality before the law (Article 8);

- Prohibition of banishment and the right to freedom of movement (Article 9);

- Freedom of speech, assembly and association (Article 10);

- Freedom of religion (Article 11);

- Rights in respect of education (Article 12);

- Rights to property (Article 13).

40. Reservations to Articles 5(a), 7(b), 9(2), 16(1)(a), (c), (f) and (g) and 16(2).

41. Reservations to Article 2, 7, 13, 14, 15, 28(1)(a).

42. Human Rights Commission of Malaysia Act 1999, Act 597.

43. 4(4): "For the purpose of this Act, regard shall be had to the Universal Declaration of Human Rights 1948 to the extent that it is not inconsistent with the Federal Constitution."

44. Article 11 of the Constitution:

(1) Every person has the right to profess and practice his religion and, subject to Clause (4), to propagate it.

(2) No person shall be compelled to pay any tax the proceeds of which are specially allocated in whole or in part for the purposes of a religion other than his own.

(3) Every religious group has the right:

(a) to manage its own religious affairs;

(b) to establish and maintain institutions for religious or charitable purposes;

(c) to acquire and own property and hold and administer it in accordance with law.

(4) State law and in respect of the Federal Territories of Kuala Lumpur and Labuan, federal law may control or restrict the propagation of any religious doctrine or belief among persons professing the religion of Islam.

(5) This Article does not authorize any act contrary to any general law relating to public order, public health or morality.

45. Mohamed Azam Mohamed Adil, "Restrictions in Freedom of Religion in Malaysia: A Conceptual Analysis with Special Reference to the Law of Apostasy", Muslim World Journal of Human Rights 4 (2007).

46. "Everyone shall have the right to freedom of thought, conscience and religion. This right shall include freedom to have or to adopt a religion or belief of his choice, and freedom, either individually or in community with others and in public or private, to manifest his religion or belief in worship, observance, practice and teaching. No one shall be subject to coercion which would impair his freedom to have or to adopt a religion or belief of his choice."

47. The UN Human Rights Committee in 1993 issued an authoritative General Comment on Article 18 of the ICCPR, making the following points: "The freedom to 'have or to adopt' a religion includes "the right to replace one's current religion or belief with another [...]".

48. Lee Hock Guan, "Affirmative Action in Malaysia", Southeast Asian Affairs (2005), 211-28. 
49. Article $160 \S 2$ : “'Malay' means a person who professes the religion of Islam, habitually speaks the Malay language, conforms to Malay custom and:

(a) was before Merdeka Day born in the Federation or in Singapore or born of parents one of whom was born in the Federation or in Singapore, or is on that day domiciled in the Federation or in Singapore; or

(b) is the issue of such a person.

50. In the Lina Joy case, the Federal Court has adopted a controversial interpretation of Article $160 \$ 2$ asserting that a Malay remains within the Islamic faith until his dying days.

51. According to Professor Kamali, during an interview in April 2010. The opposite, too, is quite clear: a non-Muslim Malaysian who converts to Islam does not become a Malay.

52. Malaysia, like other Muslim-majority countries, has made reservations inter alia on Art. 16 CEDAW, which concerns equality between men and women in all matters relating to marriage and family relations.

53. Suad Joseph Afsaneh Najmabadi (eds), Encyclopedia of Women and Islamic Cultures, vol. 2: "Family, Law, and Politics" (Leiden: Brill, 2005), 394; Nik Noriani Nik Badli Shah, Marriage and Divorce: Law Reform Within Islamic Framework (Kuala Lumpur: International Law Book Services, 2000), 47; Sayed Sikandar Shah Haneef, "Modern State-Enacted Islamic Laws: Towards a Purposive Legal Codification", Shariah Law Report 1 (2008), 39-64.

54. The guardian's unreasonable refusal to consent to his ward's marriage may be considered either as an abuse of a right or a failing in duty. If the walī withholds the consent unreasonably, the sharì ah court may act on his behalf as wali hăkim to give the consent.

55. According to Islamic family law, a marriage can be dissolved in four ways: talāq (repudiation by the husband), $\mathrm{khul}^{\prime}$ (redemption by the wife), $t a \mathrm{l}^{\prime} \mathrm{q}$ (delegated repudiation by the wife as stipulated in the marriage contract) and faskh (judicial dissolution of marriage).

56. CEDAW/C/MYS/CO/2: "The Committee is concerned about the existence of the dual legal system of civil law and multiple versions of Syariah law, which results in continuing discrimination against women, particularly in the field of marriage and family relations. The Committee is also concerned about the State party's restrictive interpretation of Syariah law, including in the recent Islamic Family Law (Federal Territories) Amendment Act 2005, which adversely affects the rights of Muslim women. The Committee is further concerned about the lack of clarity in the legal system, particularly as to whether civil or Syariah law applies to the marriages of non-Muslim women whose husbands convert to Islam."

57. Shariah Criminal Offences Enactment of Kelantan, No. 1/1985.

58. Shariah Criminal Offences Enactment (Tazir) of Terengganu No. 7/2001.

59. In December 2007, Kartika Sari Dewi Shukarno, a Malaysian who lives in Singapore, was caught drinking beer at a hotel in Kuantan, the capital of the Malaysian State of Pahang. The Sharì ah High Court in Pahang sentenced her to six strokes of the cane and fined her RM 5,000 after she had pleaded guilty. She declined to appeal and came back to Malaysia for the punishment. The appeals panel of the Shari ${ }^{-}$ah High Court in Kuantan upheld the sentence. She finally obtained the Sultan's pardon. He commuted the caning sentence to community work.

60. Press statement, "Sisters in Islam Condemns Caning of Three Muslim Women Under Syariah Law", 17 February 2010, available online at http://www.sistersinislam.org.my/index.php?option=com_con tent\&task=view\&id=986\&Itemid $=1$ (accessed on 1 July 2010).

61. Masum, "Freedom", xiii. 